\title{
Histopathologic aspects of experimental cysticercosis and in situ cytokines profile in C57BL/6 mice
}

\author{
Aspectos histopatológicos da cisticercose experimental e perfil de citocinas \\ in situ em camundongos C57BL/6 \\ Anália Cirqueira Milhomem', Amanda Juliana Soaris de Souza', Hidelberto Matos Silva², Marina Clare \\ Vinaud ${ }^{1}$, Milton Adriano Pelli de Oliveira ${ }^{1}$, Juliana Reis Machado ${ }^{1}$, Ruy de Souza Lino Júnior ${ }^{1}$
}

\begin{abstract}
Neurocysticercosis (NCC) is one of the parasitic infections that most affects the central nervous system. The knowledge regarding its immunopathogenesis and pathophysiology needs broadening. Taenia crassiceps cysticerci are used as the NCC experimental model. The aim of this work was to describe the general pathological processes and the in situ cytokine profile in C57BL/6 mice inoculated intracranially with viable T. crassiceps cysticerci. The histopathology analysis showed cysticerci in the extraparenchymal and intraventricular region, mononuclear inflammatory infiltration surrounding the parasite, microgliosis and meningitis. The analysis of the in situ immune profiles showed a predominance of the Th2 response. The IL-4 and IL-10 dosages were significantly increased in the infected group. The decrease in the INF-gamma dosage reflects the immunomodulation from the cysticerci. In conclusion, a T. crassiceps NCC infection in C57BL/6 mice triggers an inflammatory response, a predominance of Th2 type in situ profile, with mononuclear inflammatory cell infiltration, meningitis and microgliosis.
\end{abstract}

Keywords: neurocysticercosis; neglected diseases; Taenia.

\section{RESUMO}

Neurocisticercose (NCC) é uma das doenças parasitárias que mais afeta o sistema nervoso central. É necessário aprofundar o conhecimento em relação à sua imunopatogênese e patofisiologia. Os cisticercos de Taenia crassiceps são utilizados como modelo experimental para estudos da NCC. O objetivo deste trabalho foi descrever os processos patológicos gerais e o perfil de citocinas in situ em camundongos C57BL/6 inoculados via intracerebral com cisticercos viáveis de T. crassiceps. A análise histopatológica demonstrou cisticercos nas regiões extra-parenquimatosa e intraventricular, infiltrado inflamatório de células mononucleares ao redor do parasita, microgliose e meningite. A análise in situ do perfil de citocinas mostrou uma predominância da resposta Th2. As dosagens de IL-4 e IL-10 foram significativamente maiores no grupo infectado. Conclui-se que a NCC por T. crassiceps em camundongos C57BL/6 induz uma resposta inflamatória com predominância in situ de citocinas do perfil Th2, com infiltrado inflamatório de células mononucleares, meningite e microgliose.

Palavras-chave: Neurocisticercose; doenças negligenciadas; Taenia.

Taeniasis is the infection by the adult worm of the Taenia spp., while cysticercosis is the infection with the larval form of the parasite. Human cysticercosis is caused by the presence of T. solium cysticerci ${ }^{1}$. The World Health Organization considers both diseases to have been neglected ${ }^{1,2}$. The taeniasis/cysticercosis complex is a prominent cause of chronic debilitating illness, morbidity and mortality ${ }^{3}$, with worldwide prevalence, especially in rural communities of developing countries ${ }^{2}$.
Neurocysticercosis (NCC) is the most frequent parasitic infection of the central nervous system (CNS) and the main preventable cause of acquired epilepsy4. Up to $50 \%$ of the NCC cases are asymptomatic. The symptoms vary from seizures, headaches, focal neurologic deficits, cognitive decline and intracranial hypertension. The clinical manifestations depend on factors related to the parasite, such as size, location, and development stage, or factors related to the host, such as the immune response $e^{4,5,6}$. The great variety of clinical

\footnotetext{
'Universidade Federal de Goiás, Instituto de Saúde Pública, Patologia Tropical, Goiânia GO, Brasil;

${ }^{2}$ Centro Universitário Gurupi, Faculdade de Medicina, Gurupi TO, Brasil.

Correspondence: Ruy de Souza Lino Junior; Universidade Federal de Goiás; Rua 235 esq. com 1ª avenida, s/n; Setor Leste Universitário; $74605-220$,

Goiânia GO, Brasil; E-mail: ruylino@yahoo.com.br

Conflict of interest: There is no conflict of interest to declare.

Support: CNPq grant number 471243/2013-2

Received 02 October 2017; Received in final form 10 January 2018; Accepted 31 January 2018.
} 
forms are related to the modulation of the immune profile due to the presence of viable cysticerci in the brain (asymptomatic NCC), or to an intense inflammatory response (symptomatic NCC) $)^{7,8,9}$.

Usually, when an organism is exposed to a pathogen it generates an immunologic response aimed at the pathogen's destruction. The protective or pathogenic efficacy of this innate immune response greatly depends on the generation of unspecific inflammatory phenomena in the surroundings of the pathogen. The adaptive immune response relies on the selective clonal proliferation of systemic lymphoid cells followed by a differentiation of effective Th1, Th2, Treg and Th17 cells, among other profiles that induce cytokine or antibody production ${ }^{5,6,7,8,9}$.

The presence of the viable T. solium cysticercus in the brain tissue of humans triggers the increase of local inflammatory cells through the main pathways of leukocyte infiltrations, which are the parenchymal vessels, subarachnoid space and choroid space ${ }^{10}$. Within the CNS, the parasite may install itself in the brain parenchyma, subarachnoid space, ventricular system ${ }^{11}$ and, less frequently, it can be found in the brainstem ${ }^{12}$ and in the spinal cord ${ }^{13}$.

One of the experimental models used to study $T$. solium cysticercosis is T. crassiceps due to their epitope similarity $^{14}$. The immune response in mice infected with $T$. crassiceps is not well described in NCC models. However, Moura et al. ${ }^{15}$, studying an intraventricular experimental NCC model, reported that BALB/c mice presented with a predominance of a systemic mixed Th1/Th17 immune profile in the initial phases of the infection, while this gradually modified into a Th2 profile through the course of the infection.

Currently, there are five different experimental models used for NCC studies. The first one developed by Cardona et al. ${ }^{7}$, used BALB/c female mice infected with Mesocestoides corti. Subsequently, our group found that the intracranial inoculation of $T$. crassiceps cysticerci in both BALB/c and C57BL/6 mice lineages showed the susceptibility and resistance of different lineages ${ }^{16}$. Other examples are the inoculation of active T. solium oncospheres in rats $^{17}$ and the inoculation of active T. solium oncospheres in the subarachnoid space of young swine ${ }^{18}$. The most recent model described simulated the extraparenchymal racemose $\mathrm{NCC}$ in rats through the inoculation of T. crassiceps cysticerci ${ }^{19}$.

It is important to highlight that different mice lineages produce different inflammatory responses with different cellular and cytokine profiles ${ }^{20}$. The subcutaneous inoculation of T. crassiceps cysticerci allowed analysis of the kinetics of the infection in susceptible (BALB/c) and resistant (C57BL/6) mice lineages, showing a greater parasitic burden in the susceptible mice ${ }^{21}$.

Other studies of NCC models ${ }^{16}$ and in a subcutaneous model $^{22}$ showed that BALB/c mice are less efficient in the precocious destruction of the parasite, allowing its proliferation with greater inflammatory intensity in the acute phase of the infection, with a predominance of polymorphonuclear cells and macrophage infiltration. The C57BL/6 mice lineage is capable of inducing the parasite death with greater inflammatory intensity in the late phase of the infection with less tissue injury and a predominance of infiltration of mononuclear inflammatory cells. These findings confirmed the resistance profile of the C57BL/6 mice lineage in both experimental models.

To date, there is little description of the brain lesions found in the resistant mice lineage (C57BL/6) in experimental NCC, and no reports on the local immune response in this kind of infection. Therefore, the aim of this study was to describe the brain injuries and the in situ immune response in C57BL/6 mice inoculated intracranially with T. crassiceps cysticerci.

\section{METHODS}

\section{Parasite maintenance}

This study was approved by the Ethics Committee in Animal Use of the Federal University of Goiás, protocol number 065/2015. The maintenance of the T. crassiceps ORF strain was performed through successive intraperitoneal passages every 90 days in BALB/c female mice aged 8-12 weeks old ${ }^{14}$. The parasite is maintained in the animal facilities of the Tropical Pathology and Public Health Institute of the Federal University of Goiás.

\section{Infection and euthanasia of the mice}

Wild type C57BL/6 female mice aged 8-12 weeks old, weighing between 20-30 grams were used. They were divided into a control (CT) group and an infected (INF) group. Mice from the INF group were weighed, intraperitoneally anesthetized with ketamine $(100 \mathrm{mg} / \mathrm{mL})$ and xylazine $(20 \mathrm{mg} / \mathrm{mL})$ in a ratio of $0.1 \mathrm{~mL} / 10 \mathrm{~g}$. Afterwards, the animals were inoculated intracerebrally as described previously $^{16}$. The CT group $(n=9)$ received an inoculation of physiologic solution $(\mathrm{NaCl} 0.9 \%)$ in a similar volume to the INF group $(\mathrm{n}=15)$.

Ninety days after the inoculation, all the mice were euthanized and had their brains removed.

\section{Histopathology analysis}

The histopathology analysis was performed in fragments of the brain tissue using a matrix for histological slices (Insight), fixed in a solution of $4 \%$ paraformaldehyde and $70 \%$ alcohol, dehydrated with alcohol, diaphonized in xylol, and embedded in paraffin. The blocks were cut into $4 \mu \mathrm{m}$ width slices. The fragments were captured with glass slides and stained with hematoxylin-eosin ${ }^{15,16}$.

The general pathologic processes were described and classified in a semi-quantitative analysis as follows: absent when there was no compromise of the host tissue, 
score $=0$; discrete with up to $25 \%$ of area commitment, score $=1$; moderate from $26 \%$ to $50 \%$ of area commitment, score $=2$; and accentuated with more than $50 \%$ of area commitment, score $=3^{15,16}$.

\section{Immunoenzymatic assay}

After the euthanasia, a fragment of the brain tissue was frozen at $-80^{\circ} \mathrm{C}$ for the enzyme-linked immunosorbent assay (ELISA) analysis. After this it was sonicated with a solution of Tris $\mathrm{HCl}$, NP40 1\% (SIGMA) and protease inhibitor ${ }^{23}$.

The interleukin (IL)-4, IFN-gamma and IL-10 cytokines were quantified in the brain tissue homogenate solution through sandwich ELISA according to the manufacturer's instructions (BD OptEIA ${ }^{\mathrm{sx}}$ ). The IL-4 and IL-10 dosages were performed with Mouse IL-4 ELISA (Lot: 26389) and Mouse IL-10 ELISA (Lot: 20169) BD OptEIA ${ }^{\mathrm{m}}$ Sets (BD Biosciences, San Diego, CA). The IFN-gamma dosage was performed with ELISA high binding microplates sensitized with 80 $\mu \mathrm{L}$ of IFN-gamma monoclonal antibody $(5 \mu \mathrm{g} / \mathrm{mL}$ of clone XMG 1.2 in PBS). The optic density was detected through the Thermo/Labsystems microplate reader, using specific filters for each cytokine ${ }^{23}$.

\section{Statistical analysis}

The statistical analysis of the histopathology was performed using the Sigma Stat 2.3 software. The MannWhitney test was used, followed by the Bonferroni post-test. Differences were considered significant when $\mathrm{p}<0.05$.

The statistical analysis of the in situ cytokine dosage was performed with the GraphPadPrism 5.0 software, and after the establishment of distribution and variance of the samples, the T-test was used. Differences were considered significant when $\mathrm{p}<0.05$.

\section{RESULTS}

The histopathology analysis allowed the evaluation of the CNS infection of C57BL/6 mice with viable T. crassiceps cysticerci. The general pathologic processes found are described in the Table. The INF group had a greater degree of meningitis, parenchymal edema, mononuclear inflammatory cell infiltration and hemisphere compression $(p<0.05)$ than the CT group (Figures 1 and 2).

The compression of the brain hemispheres with consequent dislodgement of the medial line due to the installation and growth of the cysticerci was observed in the INF group, both in the corticomeningeal region as well as in the lateral ventricle regions (Figure 2). These injuries were not observed in the control group.

The results of the in situ cytokine analyses are shown in Figure 3. It is possible to observe a significant increase in the IL-4 and IL-10 dosages in the INF group when compared with
Table. General pathologic processes found in C57BL/6 mice inoculated intracranially with viable Taenia crassiceps cysticerci.

\begin{tabular}{lccc}
\hline Pathologic processes & $\begin{array}{c}\text { CT group } \\
\text { Median } \\
\text { (min.-max.) }\end{array}$ & $\begin{array}{c}\text { INF group } \\
\text { Median } \\
\text { (min.-max.) }\end{array}$ & $p$ \\
\hline Meningitis & $0(0-0)$ & $0(0-1)$ & $0.012^{\star}$ \\
\hline Parenchymal edema & $0(0-0)$ & $1(0-3)$ & $0.011^{\star}$ \\
\hline Hyperemia & $0(0-0)$ & $0(0-1)$ & 0.176 \\
\hline Perivasculitis & $0(0-0)$ & $0(0-2)$ & 0.177 \\
\hline Inflammatory infiltration (MN) & $0(0-0)$ & $0(0-2)$ & $0.008^{*}$ \\
\hline Microgliosis & $0(0-0)$ & $0(0-2)$ & 0.106 \\
\hline Perivascular edema & $0(0-0)$ & $0(0-1)$ & 0.491 \\
Ventriculomegaly & $0(0-0)$ & $0(0-3)$ & 0.177 \\
Hippocampus alterations & $0(0-0)$ & $0(0-3)$ & 0.291 \\
Choroiditis & $0(0-0)$ & $0(0-0)$ & 1 \\
\hline Ependymitis & $0(0-0)$ & $0(0-0)$ & 1 \\
Tissue loss & $0(0-0)$ & $0(0-3)$ & 0.108 \\
\hline Hemorrhage & $0(0-0)$ & $0(0-0)$ & 1 \\
\hline Hemisphere compression & $0(0-0)$ & $2(0-3)$ & $0.006^{*}$ \\
\hline
\end{tabular}

CT: control group; INF: infected group; MN: mononuclear cells; * statistically significant differences $(p<0.05)$.

the CT group ( $\mathrm{p}<0.05)$. There were no differences in the IFNgamma dosages between the two groups.

\section{DISCUSSION}

This study showed the in situ histopathology and immune response of a resistant mice lineage (C57BL/6) given an intracerebral inoculation of $T$. crassiceps cysticerci. The mechanisms in which the brain injuries are induced by the presence of cysticerci depend on a combination of several factors, such as the site of implantation of the parasite and the host immune-inflammatory response $e^{6,11}$, which is mediated by cytokines produced by resident and infiltrated cells, which in turn are activated by the cysticerci antigens ${ }^{4,24}$.

The inoculated cysticerci were located in the ventricles or in the extraparenchymal/meningocortical region and triggered a discrete inflammatory response with little mononuclear inflammatory cell infiltration. As well, when the parasite installed in the surroundings of the meninx, it was capable of inducing discrete meningitis. These findings are in accordance with other reports on the location and inflammatory response of the T. crassiceps experimental model ${ }^{7,9,16}$ as well as the human NCC inflammatory response $\mathrm{e}^{5,11}$.

The histopathology findings described in this study are in accordance with Matos-Silva et al. ${ }^{16}$, who induced an experimental intraventricular NCC with T. crassiceps cysticerci in $\mathrm{C} 57 \mathrm{Bl} / 6$ mice and described discrete mononuclear inflammatory cell infiltration, parenchymal edema and meningitis. The findings described by Matos-Silva et al. ${ }^{16}$ are similar to the those described in this study regarding the lineage, age, weight and sex of the animals and the 

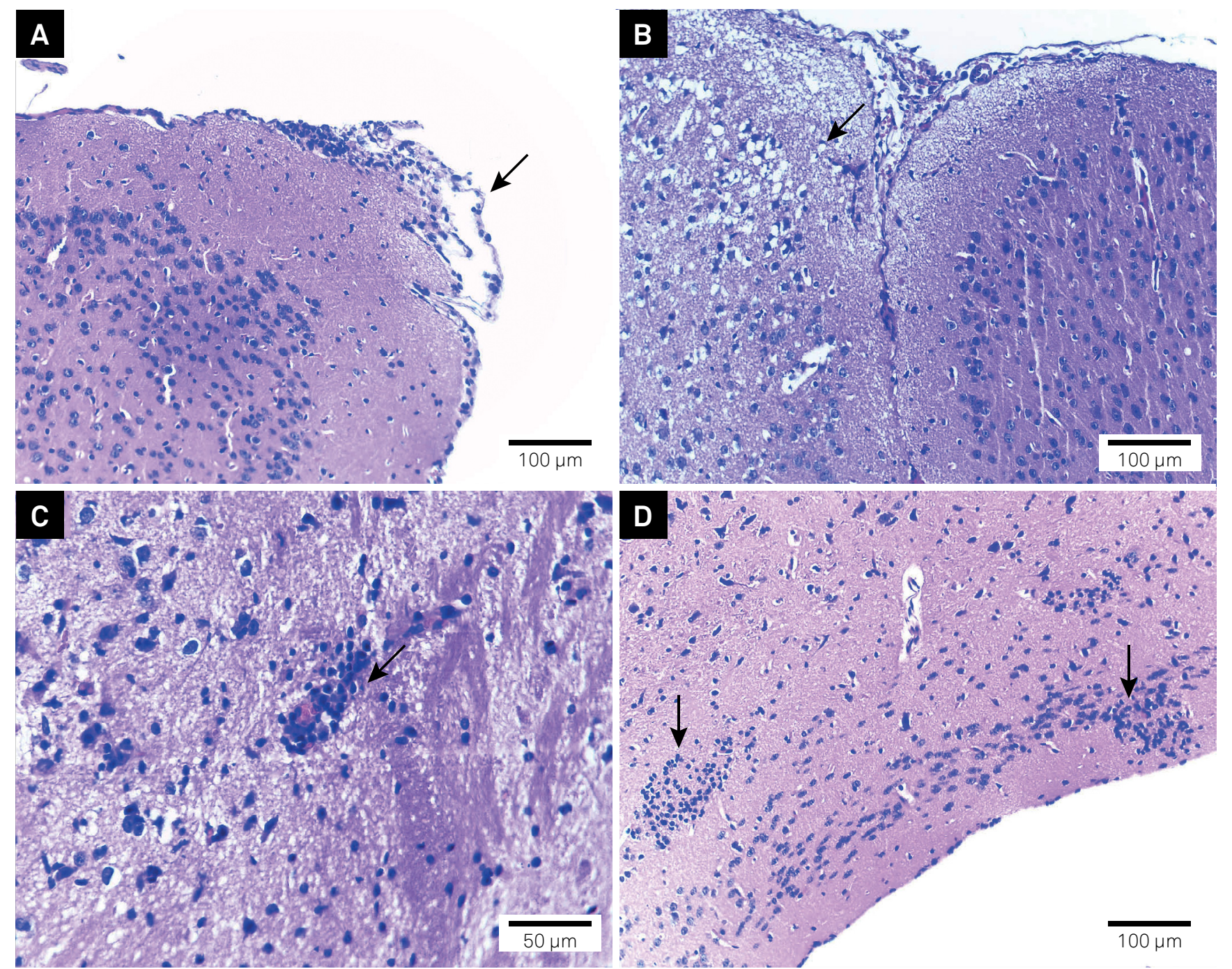

Figure 1. Photomicrograph of the general pathologic processes found in C57BL/6 mice inoculated intracranially with viable Taenia crassiceps cysticerci after 90 days. A. Discrete meningitis in the infected (INF) group (arrow) (scale = $100 \mu$ m); B. Accentuated parenchymal edema in the INF group (arrow) (scale $=100 \mu \mathrm{m})$; C. Moderate perivasculitis in the INF group $(\operatorname{arrow})(\mathrm{scale}=50 \mu \mathrm{m})$; D. Moderate microgliosis in the INF group (arrows) (scale $=100 \mu \mathrm{m})$. H\&E.

parasite used. However, in our study, the localization of the parasite within the brain was mainly in the meningocortical region, differing from the previously-cited study. This difference is important in the description of the host response to the parasite, due to the fact that parenchymal NCC is associated with seizures and focal neurological signs and is the form that presents with greater inflammation when treated ${ }^{26}$. The human extraparenchymal NCC is associated with high mortality rates due to the increase in intracranial pressure ${ }^{6}$.

The hemispheric compression caused by the presence and growth of the cysticerci was accentuated in the mice used in this study. The main consequence of this process is the increase in the intracranial pressure which may lead to obstruction of CSF and edema in different degrees of severity $^{11,24}$. The presence of parenchymal edema in the INF group of this study, even at 90 days after the inoculation, may have been due to this compression process.
The in situ cytokine dosage results found in this study suggest the predominance of a Th2 immune profile at 90 days after the inoculation of $T$. crassiceps cysticerci. This may be inferred by the significantly higher concentrations of IL-4 in the INF group when compared with the CT group and also because of the lack of difference in the IFN-gamma concentrations. It is important to highlight that, within the brain, the inflammatory and immune processes occur in a unique form, which may alter the expected order of inflammation, tissue injury, damage to the host, death of the parasite and resolution of the infection ${ }^{24,25}$.

The brain, as an immunoprivileged organ, attenuates the inflammation in its tissue because it can threaten the brain's integrity and function ${ }^{11,24}$. This protective mechanism is due to passive factors, such as the presence of the blood brain barrier and the intracerebral circulation, as well as active factors such as immunosuppressive cytokine production, 


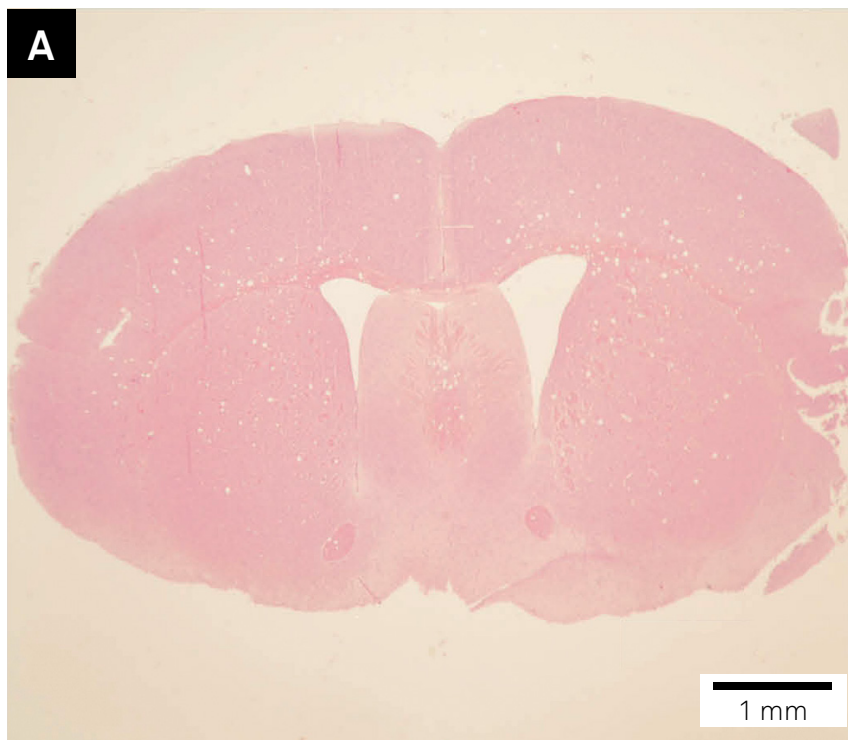

B
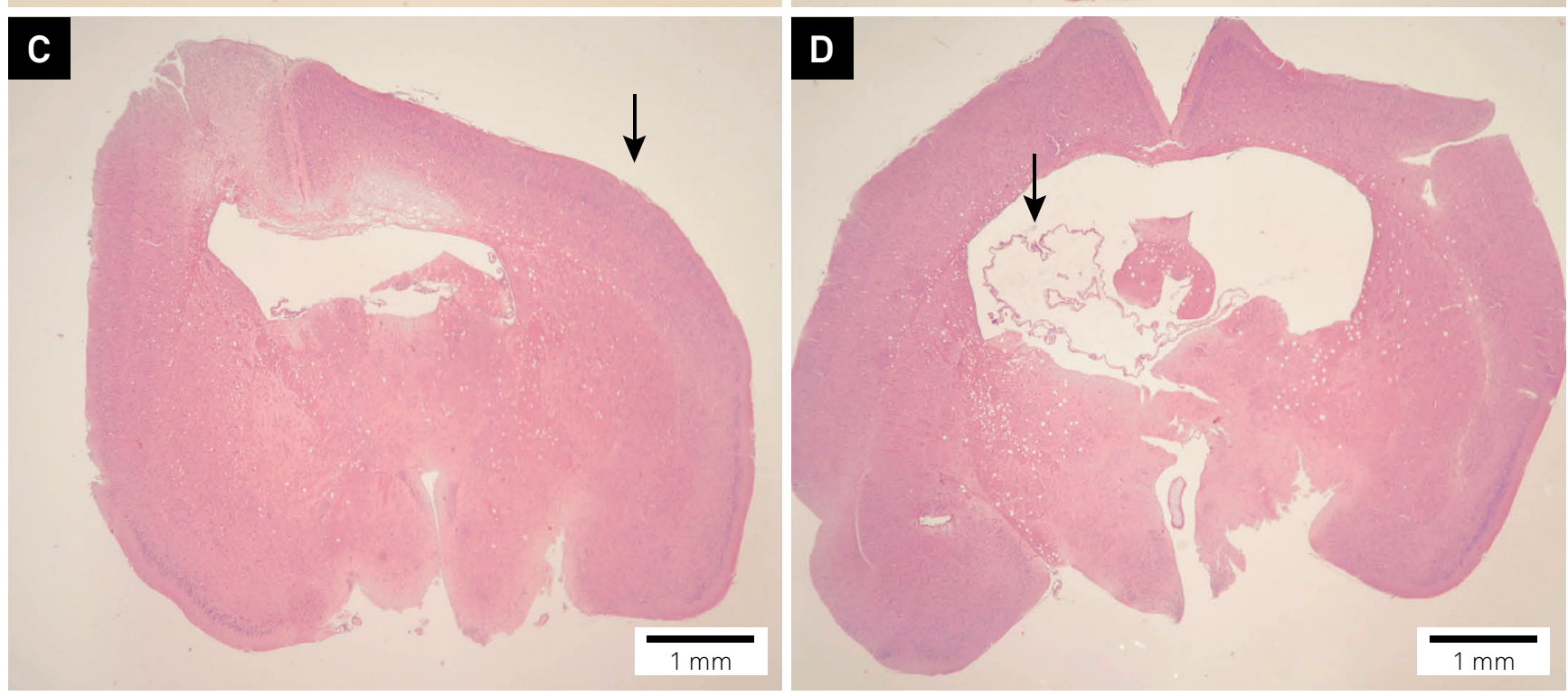

Figure 2. Mesoscopic image of the brains from C57BL/6 mice. A. Absence of hemisphere compression in a mouse from the control (CT) group. B, C and D. Hemisphere compression, dislodgement of the medial line, hippocampus and lateral ventricle in mice inoculated intracranially with Taenia crassiceps cysticerci (INF group). In D, the arrow shows the presence of a viable cysticercus in the lateral ventricle. Scale bar $=1 \mathrm{~mm}$. H\&E.

neuropeptides, limitation in the MHC class I and II expression, complement regulatory proteins and NK cell inhibitors, which also contribute to the immune privilege $\mathrm{e}^{27,28}$. These factors act as a protective factor regarding NCC, preventing damage to the brain tissue and favoring the extension of the parasite's life within the brain ${ }^{29}$.

Moura et al. ${ }^{15}$ reported that BALB/c mice, experimentally inoculated intracranially with $T$. crassiceps cysticerci, did not show significant differences in the in situ dosage of cytokines in spite of higher concentrations of IFN-gamma than IL-4, confirming a Th1 immune profile, allowing the parasite survival. In our study, the C57BL/6 mice inoculated with the same parasite showed a predominance of the Th2 immune profile as an attempt to contain the parasite growth.
It is important to highlight the immunomodulation capacity of the cysticerci, which is also responsible for the immune profile observed in C57BL/6 mice. The parasite's antigens stimulate the production of antibodies and the release of chemical mediators that are unable to destroy the cysticercus. This happens because the parasite simultaneously modulates the action of these immune components and becomes viable for a longer period of time ${ }^{30}$. Thus, it sways the immune profile from a Th1 response to a Th2 response, which protects the tissue from damage, activates macrophages with lower microbicide potential, and generates the activation and expansion of plasmocytes. As well, the IgE secretion, presence of eosinophils, mastocytes and basophils are unable to destroy the parasite ${ }^{6}$. 

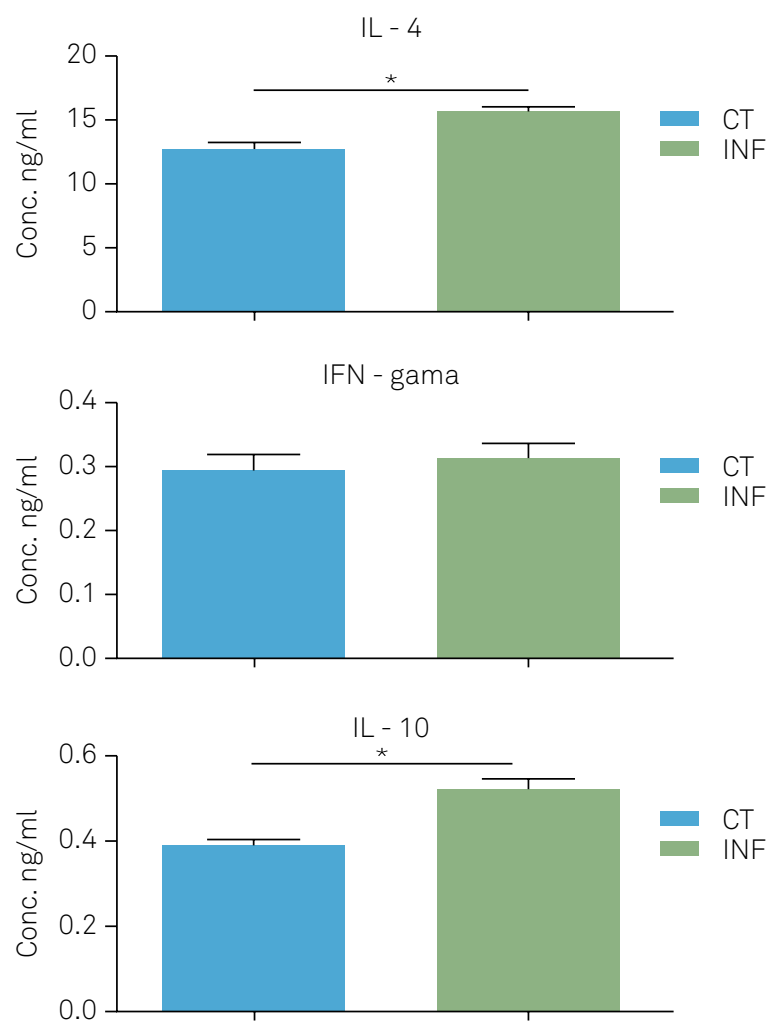

CT: control group; INF: infected group. *statistical difference between groups $(p<0.05)$, TTest.

Figure 3. In situ cytokine dosage from C57BL/6 mice intracranially inoculated with Taenia crassiceps cysticerci, 90 days after the inoculation.
The IL-10 dosage detected in this study shows that the presence of this cytokine within the brain tissue modulates the Th1 and Th2 immune responses. Interleukin-10 is a potent inhibitor of the antigen presentation, and of the mediators and pro-inflammatory cytokine production by macrophages, dendritic cells and TH1 cells ${ }^{30}$. It has an important regulatory role on the host inflammatory response during the infection. The inflammation is essential at the beginning of the response against the pathogen, but this must be controlled so it does not result in severe inflammatory complications ${ }^{31}$. It is also capable of regulatory $\mathrm{T}$ cell lymphocyte activation, which decreases the tissue damage ${ }^{30}$. Therefore, the statistically higher concentration of IL-10 in the infected group in our study demonstrates that it is regulating the immune response in the mice, swaying the immune response towards the Th2 immune profile, which decreases the parenchymal damage and contributes to the parasite survival.

Therefore, when the immune aspects are correlated with the histopathology described in this study, it is possible to conclude that the infection of T. crassiceps in C57BL $/ 6$ mice triggered an inflammatory response with a predominant Th2 and Treg in situ response. These facts are reflected in the control of the intensity of the general pathologic processes, such as meningitis, microgliosis, mononuclear inflammatory cell infiltration and compression of the brain hemispheres.

\section{References}

1. Nash TE, Mahanty S, Garcia HH. Neurocysticercosis-more than a neglected disease. PLoS Negl Trop Dis. 2013 Apr;7(4):e1964. https://doi.org/10.1371/journal.pntd.0001964

2. World Healt Organization - WHO. WHO 2011. Report of the WHO Expert Consultation on Foodborne Trematode Infections and Taeniasis/Cysticercosis, 2009 Oct 12-16; Vientiane, Lao People's Democratic Republic. Geneva: World Healt Organization; 2011.

3. Flisser A, Ávila G, Maravilla P, Mendlovic F, León-Cabrera S, Cruz-Rivera $\mathrm{M}$ et al. Taenia solium: current understanding of laboratory animal models of taeniosis. Parasitology. 2010 Mar;137(3):347-57. https://doi.org/10.1017/S0031182010000272

4. Garcia HH, Nash TE, Del Brutto OH. Clinical symptoms, diagnosis, and treatment of neurocysticercosis. Lancet Neurol. 2014 Dec;13(12):1202-15. https://doi.org/10.1016/S1474-4422(14)70094-8

5. Sciutto E, Chavarria A, Fragoso G, Fleury A, Larralde C. The immune response in Taenia solium cysticercosis: protection and injury. Parasite Immunol. 2007 Dec;29(12):621-36. https://doi.org/10.1111/j.1365-3024.2007.00967.x

6. Fogang YF, Savadogo AA, Camara M, Toffa DH, Basse A, Sow AD et al. Managing neurocysticercosis: challenges and solutions. Int J Gen Med. 2015 Oct;8:333-44. https://doi.org/10.2147/IJGM.S73249

7. Cardona AE, Restrepo BI, Jaramillo JM, Teale JM. Development of an animal model for neurocysticercosis: immune response in the central nervous system is characterized by a predominance of $\gamma \delta \mathrm{T}$ cells. J Immunol. 1999 Jan;162(2):995-1002.

8. Tuero I, Palma S, Cabeza F, Saleemi S, Rodriguez S, Gonzales I et al.; Cysticercosis Working Group in Perú. A comparative study of peripheral immune responses to Taenia soliumin individuals with parenchymal and subarachnoid neurocysticercosis. PLoS Negl Trop Dis. 2015 Oct;9(10):e0004143. https://doi.org/10.1371/journal.pntd.0004143

9. Fleury A, Cardenas G, Adalid-Peralta L, Fragoso G, Sciutto E. Immunopathology in Taenia solium neurocysticercosis. Parasite Immunol. 2016 Mar;38(3):147-57. https://doi.org/10.1111/pim.12299

10. Ransohoff RM, Kivisäkk P, Kidd G. Three or more routes for leukocyte migration into the central nervous system. Nat Rev Immunol. 2003 Jul;3(7):569-81. https://doi.org/10.1038/nri1130

11. Del Brutto OH. Neurocysticercosis. Handb Clin Neurol. 2014;121:1445-59. https://doi.org/10.1016/B978-0-7020-4088-7.00097-3

12. Del Brutto OH, Del Brutto VJ. Isolated brainstem cysticercosis: a review. Clin Neurol Neurosurg. 2013 May;115(5):507-11. https://doi.org/10.1016/j.clineuro.2012.12.026

13. Cárdenas G, Valdez R, Sáenz B, Bottasso O, Fragoso G, Sciutto $E$ et al. Impact of Taenia solium neurocysticercosis upon endocrine status and its relation with immunoinflammatory parameters. Int J Parasitol. 2012 Feb;42(2):171-6. https://doi.org/10.1016/j.ijpara.2011.11.009

14. Vaz AJ, Nunes CM, Piazza RM, Livramento JA, Da Silva MV, Nakamura PM et al. Immunoblot with cerebrospinal fluid from patients with neurocysticercosis using antigen from cysticerci of Taenia solium and Taenia crassiceps. Am J Trop Med Hyg. 1997 Sep;57(3):354-7. https://doi.org/10.4269/ajtmh.1997.57.354

15. Moura VB, Lima SB, Matos-Silva H, Vinaud MC, Loyola PR, Lino RS. Cellular immune response in intraventricular experimental neurocysticercosis. Parasitology. 2016 Mar;143(3):334-42. https://doi.org/10.1017/S0031182015001572 
16. Matos-Silva H, Reciputti BP, Paula EC, Oliveira AL, Moura VB, Vinaud MC et al. Experimental encephalitis caused by Taenia crassiceps cysticerci in mice. Arq Neuropsiquiatr. 2012 Apr;70(4):287-92. https://doi.org/10.1590/S0004-282X2012005000010

17. Verastegui MR, Mejia A, Clark T, Gavidia CM, Mamani J, Ccopa F et al. Novel rat model for neurocysticercosis using Taenia solium. Am J Pathol. 2015 Aug;185(8):2259-68. https://doi.org/10.1016/j.ajpath.2015.04.015

18. Fleury A, Trejo A, Cisneros H, García-Navarrete R, Villalobos N, Hernández M et al. Taenia solium: development of an experimental model of porcine neurocysticercosis. PLoS Negl Trop Dis. 2015 Aug;9(8):e0003980. https://doi.org/10.1371/journal.pntd.0003980

19. Hamamoto Filho PT, Fabro AT, Rodrigues MV, Bazan R, Vulcano LC, Biondi GF et al. Taenia crassiceps injection into the subarachnoid space of rats simulates radiological and morphological features of racemose neurocysticercosis. Childs Nerv Syst. 2017 Jan;33(1):119-23. https://doi.org/10.1007/s00381-016-3239-3

20. Fragoso G, Meneses G, Sciutto E, Fleury A, Larralde C. Preferential growth of Taenia crassiceps cysticerci in female mice holds across several laboratory mice strains and parasite lines. J Parasitol. 2008 Apr;94(2):551-3. https://doi.org/10.1645/GE-1287.1

21. Freitas AA, Moura VB, Gonçalves SF, Rodrigues AA, Félix RM, Soares TP et al. Kinetics of the inflammatory response in subcutaneous cysticercosis induced in mice by Taenia crassiceps. J Comp Pathol. 2012 Aug-Oct;147(2-3):267-74. https://doi.org/10.1016/j.jcpa.2011.12.009

22. Pereira İM, Lima SB, Freitas AA, Vinaud MC, Junior RS. EXPERIMENTAL SUBCUTANEOUS CYSTICERCOSIS BYTaenia crassiceps IN BALB/c AND C57BL/6 MICE. Rev Inst Med Trop São Paulo. 2016 Jul;58(0):55. https://doi.org/10.1590/S1678-9946201658055

23. Oliveira MA, Santiago HC, Lisboa CR, Ceravollo IP, Trinchieri G, Gazzinelli RT et al. Leishmania sp: comparative study with Toxoplasma gondii and Trypanosoma cruzi in their ability to initialize
IL-12 and IFN- $\gamma$ synthesis. Exp Parasitol. 2000 Jun;95(2):96-105. https://doi.org/10.1006/expr.2000.4523

24. Sotelo J, Marin C. Hydrocephalus secondary to cysticercotic arachnoiditis. A long-term follow-up review of 92 cases. J Neurosurg. 1987 May;66(5):686-9. https://doi.org/10.3171/jns.1987.66.5.0686

25. Bueno EC. Cysticercosis and the immunossupression: what are the mechanisms involved? Arq Neuropsiquiatr. 2012 Apr;70(4):243-4. https://doi.org/10.1590/S0004-282X2012000400002

26. Cangalaya C, Zimic M, Marzal M, González AE, Guerra-Giraldez C, Mahanty S et al.; Cysticercosis Working Group in Peru. Inflammation caused by praziquantel treatment depends on the location of the Taenia solium cysticercus in porcine neurocysticercosis. PLoS Negl Trop Dis. 2015 Dec;9(12):e0004207. https://doi.org/10.1371/journal.pntd.0004207

27. Ferguson TA, Griffith TS. A vision of cell death: insights into immune privilege. Immunol Rev. 1997 Apr;156(1):167-84. https://doi.org/10.1111/j.1600-065X.1997.tb00967.x

28. Riemersma SA, Jordanova ES, Schop RF, Philippo K, Looijenga $\mathrm{LH}$, Schuuring E et al. Extensive genetic alterations of the $H L A$ region, including homozygous deletions of HLA class II genes in B-cell lymphomas arising in immune-privileged sites. Blood. 2000 Nov;96(10):3569-77.

29. Gimsa U, Mitchison NA, Brunner-Weinzierl MC. Immune privilege as an intrinsic CNS property: astrocytes protect the CNS against T-cell-mediated neuroinflammation. Mediators Inflamm. 2013;2013:320519. https://doi.org/10.1155/2013/320519

30. Terrazas LI. The complex role of pro- and anti-inflammatory cytokines in cysticercosis: immunological lessons from experimental and natural hosts. Curr Top Med Chem. 2008;8(5):383-92. https://doi.org/10.2174/156802608783790848

31. Hedrich CM, Bream JH. Cell type-specific regulation of IL-10 expression in inflammation and disease. Immunol Res. 2010 Jul;47(1-3):185-206. https://doi.org/10.1007/s12026-009-8150-5 